\title{
Big shoes to fill
}

\section{Jamie Trapp ${ }^{1}$}

Published online: 8 February 2019

(c) Australasian College of Physical Scientists and Engineers in Medicine 2019
It is with some nervousness that I take on the role of Editor in Chief of this journal. As I look at how previous editors have advanced the journal from a local scientific newsletter $[1-3]$ to fully fledged journal $[4,5]$ and then to the current status of a truly international journal which receives over 90\% of manuscripts from countries other than Australia and New Zealand, I understand that there are very big shoes to fill.

It is well documented that Kenneth Clarke was the editor for the first 11 volumes from 1977, although his involvement was far more than just those volumes, stretching back to 1959 when he initiated the Australasian Newsletter of Medical Physics [1]. From these humble beginnings successive editors (Allun Beddoe, Tim van Doorn, Sergei Zavgorodni, John Pattison and Martin Caon) have successfully moved with the times to keep the journal alive and topical.

For example, Sergei Zavgorodni implemented email submissions, placement of APESM articles on the web, and electronic handling of manuscripts [6], which enabled faster submissions internationally and undoubtedly was the catalyst for rapidly increasing numbers of submissions. John Pattison undertook several steps to evolve the journal, including indexing with major databases and the appointment of Associate Editors to help with the growing workload [7].

When Martin Caon (the longest serving editor since the journal became a journal) took the role in 2006 the journal was still locally printed, with editors driving their car to a local printer to collect the paper copies and then deliver them to a sheltered workshop for packaging and addressing. Martin's tenure saw the change to publishing with the Springer-Nature publishing house which now handles such tasks, including managing an online submission system (Editorial Manager) and the move to online publishing [8]. Martin also grew the use of editorials, which is an important

Jamie Trapp

j.trapp@qut.edu.au

1 School of Chemistry, Physics, and Mechanical Engineering, Queensland University of Technology, Brisbane, Australia avenue for people to share their wisdom on a variety of topics [5, 9-19], including Martin's own wisdom gained in his role [20-31].

When Martin commenced as Editor in 2005 there were approximately 50 manuscripts submitted per year, with almost as many accepted papers. In 2018 the journal received 460 manuscripts, with 83 articles published, illustrating its growing visibility internationally. Amazingly, Martin was still able to manually track each manuscript from submission to final disposition-a task which is beyond the mere mortal who has to follow in his footsteps.

Importantly, many who publish research work for institutions where journal metrics (rightly or wrongly) play a major role, and this leads into the decision of where to submit manuscripts. My predecessors managed to take what essentially started as a newsletter and develop it firstly into a journal, and then an international journal with a growing impact factor and growing international reputation.

Therefore, the nervousness that I feel in taking this role is living up to the outstanding work of those before me while ensuring the journal still serves the ACPSEM members (the owners of the journal) and the organisations for whom this is the official journal.

\section{References}

1. Clarke K (2007) An historical perspective of the APESM. Aust Phys Eng Sci Med 30:xiv

2. Clarke K (1984) Twenty five years on. Aust Phys Eng Sci Med 7(4): 140

3. Clarke K (1977) Australasian physical sciences in medicine. Aust Phys Sci Med 1(1):2

4. Caon M (2018) Operational statistics for the APESM journal (2014-2016). Aust Phys Eng Sci Med 40(3):487-489

5. Crowe SB, Kairn T (2017) Medical physics publishing in a changing research environment: the Australasian Physical \& Engineering Sciences in Medicine 40th anniversary editorial. Aust Phys Eng Sci Med 40(4):771-776

6. Zavgorodni S (2002) Editorial. Aust Phys Eng Sci Med 25(4):xii

7. Pattison J (2005) Editorial. Aust Phys Eng Sci Med 28(4):xiii 
8. Caon M (2018) Hasta la vista hardcopy: APESM bids adieu to soft-bound paper issues and says ciao to on-line screen-read e-issues. Aust Phys Eng Sci Med 41(3):563-564

9. Smith I (2016) Transforming the ACPSEM for a sustainable future. Australas Phys Eng Sci Med 39(1):1-4. https://doi. org/10.1007/s13246-016-0434-1

10. Haworth A (2016) Brachytherapy: a dying art or missed opportunity? Australas Phys Eng Sci Med 39(1):5-9. https://doi. org/10.1007/s13246-016-0430-5

11. Bartlett $M$ (2016) From the inside out: radionuclide radiation therapy. Aust Phys Eng Sci Med 39(2):357-359

12. Rykers K (2016) The impact of diversity, bias and stereotype: expanding the Medical Physics and Engineering STEM workforce. Aust Phys Eng Sci Med 39(3):593-600

13. Sykes PJ (2016) The ups and downs of low dose ionising radiobiology research. Aust Phys Eng Sci Med 39(4):807-811

14. Diffey J (2017) How many physicists does it take to test a mammography unit? Aust Phys Eng Sci Med 40(1):1

15. McRobbie D (2017) Both sides now: diagnostic imaging medical physics in two hemispheres. Aust Phys Eng Sci Med 40(2):269-272

16. Corde S (2017) Best of both worlds. Aust Phys Eng Sci Med 40(3):483-485

17. Wilfert L (2018) Drivers of change. Aust Phys Eng Sci Med 41(2):357-360

18. Dempsey C (2018) Medical physics workforce modelling: do we need what we want? Aust Phys Eng Sci Med 41(3):565-566

19. Perdomo A (2018) Standardised quality control and quality assurance activities in radiology across Australia and New Zealand: in search of the Holy Grail. Aust Phys Eng Sci Med 41(4):775-777

20. Caon M (2006) Just say yes. Aust Phys Eng Sci Med 29(4):xiv
21. Caon M (2007) Plagiarism in scientific/medical physics publishing. Aust Phys Eng Sci Med 30(4):xi-xii

22. Caon $M(2007)$ Why publish in prestigious internatinal journals? Aust Phys Eng Sci Med 30(1):xii-xiii

23. Caon M (2008) Peer review: how to be a good reviewer. Aust Phys Eng Sci Med 31(4):xiii-xiv

24. Caon M (2008) Fact impactor tactic map for impact factor. Aust Phys Eng Sci Med 31(1):xiv-xvi

25. Caon M (2015) What should not be in a manuscript submitted to a scientific journal. Aust Phys Eng Sci Med 38(2):203-204. https ://doi.org/10.1007/s13246-015-0350-9

26. Caon M (2016) Abbreviations, initialism and acronyms: their use in medical physics (THUMP). Aust Phys Eng Sci Med 39(1):1112. https://doi.org/10.1007/s13246-016-0423-4

27. Caon M (2016) WIMPs $=1 / 2 \times($ ROMPs + DIMPs). Aust Phys Eng Sci Med. https://doi.org/10.1007/s13246-016-0450-1

28. Caon M (2016) There are too many medical physics journals!. Aust Phys Eng Sci Med 39(4):813-816

29. Caon M (2017) Gaming the impact factor: where who cites what, whom and when. Aust Phys Eng Sci Med 40(2):273-276

30. Caon M (2017) Multiple authorship of scientific manuscripts. Aust Phys Eng Sci Med 40(1):7-9

31. Caon M (2018) Revise before review; reject without review; reject after review": why manuscripts are rejected. Aust Phys Eng Sci Med 41(1):3-5

Publisher's Note Springer Nature remains neutral with regard to jurisdictional claims in published maps and institutional affiliations. 